\title{
ART FESTIVALS AND RURAL REVITALIZATION: ORGANIZING THE OKU-NOTO TRIENNALE IN JAPAN
}

\author{
Agnès Sarale $^{1}$, Hironori Yagi ${ }^{*}$, Menelaos Gkartzios ${ }^{3}$, Keishi Ogawa² \\ ${ }^{1}$ Agro Paris Tech, Paris, France \\ ${ }^{2}$ Department of Agricultural and Resource Economics, the University of Tokyo, Tokyo, Japan \\ ${ }^{3}$ Centre for Rural Economy, Newcastle University, Newcastle upon Tyne, United Kingdom \\ *Corresponding author: E-mail: ayouken@mail.ecc.u-tokyo.ac.jp
}

Citation: Sarale, A., Yagi, H., Gkarzios, M, Ogawa, K., 2020. Art Festivals and Rural Revitalization: Organizing the Oku-Noto Triennale in Japan. J. Asian Rur. Stud. 4(1): 23-36

\begin{abstract}
Organizing rural art festivals is considered an effective intervention in support of rural revitalization in the face of aging and population decline in Japan. Several studies have identified the impacts of art festivals on economic and social rural development internationally. Little research, however, has focused on the management process of such festivals. The objective of this paper is to identify and examine the management processes crucial to an arts festival's success, especially in terms of preparation, organization and community outreach. We focus on the first edition of the Oku-Noto Triennale, which took place in Suzu City, a remote coastal area of rural Japan in 2017. The Triennale was held from September 3, 2017 to October 22, 2017 with 39 groups of artists. Data for this study was primarily obtained through qualitative interviews with Suzu's City Office, the coordinator of the Art Front Gallery, a Tokyo-based art gallery, and community members involved in the festival. Our case study revealed that several factors were found to be crucial to the festival's success. The organizing team's flexibility, for example, assigning additional municipalities' employees to site operations, was pivotal. Experienced actors, such as outside professionals and residents with prior experience organizing previous projects, who could address and overcome the difficulties they faced during the preparation, also deserve mention. The festival also succeeded due to the involvement of residents. In total, 1,176 people were involved as registered supporters, and 434 residents were involved as local volunteers during the festival (counted in working-days). The organizing team worked hard to convey the underlying concept of the art festival to the local residents. By organizing the festival, the residents met and formed bonds with new people and also strengthened their ties with one another.
\end{abstract}

Keywords : Rural Development; Art Festival; Community Revitalization; Local Involvement

\section{Introduction}

Japan continues to experience severe population decline and an aging population. Although socioeconomic development has increased life expectancy in Japan, it has also led to a decrease in birth rates. As a result, Japan has become a "super aging society." The effects of aging and population decline have been especially severe in rural Japan, as young people tend to migrate to urban areas for studies or employment (Kudo et al., 2015). 
A number of projects have been designed to revitalize rural Japan - in particular, artrelated projects and events have been designed and implemented to alleviate these issues (Kobayashi, 2014; Favell, 2015). For instance, the Echigo-Tsumari Art Triennale, organized by the Tokyo-based Art Front Gallery (AFG), has been one of the most successful rural revitalization programs and prolific art events in the country and internationally (Demetriou, 2009; Maerkle, 2017; Whatley, 2018). Since 2000, the outdoor art festival Triennale has been held in Niigata Prefecture, a mountainous and disadvantaged rural area. The festival involves a large-scale display of artworks; in fact, the outdoor display spans an area of $760 \mathrm{~km}^{2}$ (Echigo-Tsumari Exective Committee, 2018). The festival aims to enhance people's awareness of the natural and social environment. To this end, the festival seeks to encourage visitors to learn more about the area and its surroundings, its history, traditions, residents, and spirit. At the same time, the festival adopts socially engaged contemporary art practices, with many local groups involved in the direct production of artworks. The festival seeks not only to enable common people to enjoy and appreciate art, but to involve them directly in art making (Kitagawa, 2015).

Several studies have identified the impacts of art festivals on economic and social rural development internationally (Gibson et al., 2010a; Gibson et al., 2010b; Gursoy et al., 2004; Karasawa, 2007; Kobayashi, 2005; Mahon and Hyyrylaïnen, 2017; Sumi, 2013). Similarly, research is expanding on what artistic practice can offer to rural communities (Crawshaw and Gkartzios, 2017; 2018) and rural research (Gkartzios and Crawshaw, 2019). Little research, however, has focused on the management process of such festivals. This case study of the first edition of the Oku-Noto Triennale, a new rural art festival which took place in Japan, aims to identify and examine the management processes crucial to its success, especially in terms of preparation, organization and community outreach. In particular, we examine 1) how the preparations for the first edition of this festival were managed, and 2) the way the local population became involved in the preparation and organization of this festival.

\section{Methodology}

The first edition of Oku-Noto Triennale was held in the autumn of 2017 in Suzu, Ishikawa Prefecture. The city of Suzu is located at the tip of the Noto Peninsula in Honshu Island, and is surrounded by the Sea of Japan. As of 2015, Suzu had a population of 14,625 (Statistics Bureau of Japan, 2015). A remote rural area, Suzu has also been adversely affected by population decline and aging. In fact, Suzu's population has been decreasing steadily: between 2000 and 2015, its population decreased by as much as $25 \%$. Simultaneously, the number of inhabitants aged 60 and above increased by $40-50 \%$.

Data for this study was primarily obtained through qualitative interviews with a wide range of people involved in the festival's organization; the interviews usually lasted between one to two hours and were held in Japanese. Official information pertaining to the festival's management, including the strategies employed in the organization of the festival, was obtained from a representative from Suzu's City Office and a coordinator of AFG. To gauge the extent of the residents' engagement in the festival, we 
interviewed the representative of Kamikuromaru, a community located in the city of Suzu. The representative was also involved in the festival. We also interviewed three female members of a local patchwork group, who were involved in the making an artwork exhibited at the festival. Following our site visit in October 2017 during the art festival, we conducted interviews in November 2017 with several people affiliated with the AFG; these interviews were conducted in Tokyo. Our other interviews were conducted in Suzu in January 2018.

\section{Management of the festival's organization}

\subsection{General description and background}

Rather than organizing festivals and displays in formal art spaces (such as museums, galleries or other exhibition halls), the Oku-Noto Triennale Executive Committee stages its festival outdoors or in old, abandoned houses, other community sites (such as schools, bath houses, etc.) and outdoor (open) spaces. The display of artworks for the Oku-Noto Triennale spanned across all 10 districts in the city of Suzu. AFG also sought to ensure that the artworks displayed were in harmony with the natural environment and history of Suzu. As mentioned above, the purpose of this festival was to create awareness about the city's unique cultural and environmental features. The Triennale was held from September 3, 2017 to October 22, 2017. As many as 40 artworks created by 39 groups of artists (29 from Japan and 10 from abroad) were displayed at this festival (Oku-noto Triennale Executive Committee, 2018). Admission tickets were sold, either per artwork or as "all-artworks" pass. Visitors had free access to the ten districts where the artworks were displayed. In addition, visitors also had the option of taking bus tours accompanied by local people acting as guides, and introducing the local community to visitors through their anecdotes and stories. In fact, as many as four guided bus tours were scheduled every day; visitors also had the option of hiring bikes for rent.

This festival was funded by the national government, the city of Suzu, and the sales of entrance tickets (Table 1). The festival was also supported by private funds. Notably, the city used funds that were initially earmarked for a nuclear plant project. However, the nuclear project was dropped as a result of the residents' opposition.

The festival was first conceived by the Chamber of Commerce of Suzu, and the idea was pitched to AFG in 2013 drawing on AFG's successful organization of art festivals in remote upland and island locations (e.g., Echigo-Tsumari Art Triennale; Setouchi Triennale). AFG's involvement in the project started in 2014, after the Chamber of Commerce agreed to involve the municipality of Suzu in the project. Local authorities in Suzu were convinced that the project was necessary to alleviate the adverse effects of the city's severe population decline and aging. At the time, the local government was also involved in addressing population decline, and its measures to this end were mainly based on Japan's Local Autonomy Act (Kihon Kousou). To stem population decline, the local government sought to preserve and promote "Satoyama," a global agricultural patrimony associated with sustainable land management practices, and "Satoumi," involving marine and coastal ecosystems. The government also sought to attract prospective migrants to the city of Suzu. In short, the government aimed to make the 
region attractive again. In fact, the Oku-Noto Triennale was organized to fulfil the same objectives.

Table 1. Budget of the festival and sources

\begin{tabular}{llr}
\hline \hline & \multicolumn{1}{c}{ Source } & Amount (JPY) \\
\hline Subsidies and donations & National government & $100 \mathrm{mil}$ \\
& Private funds & $30 \mathrm{mil}$ \\
& The City of Suzu & $240 \mathrm{mil}$ \\
\hline Ticket sales & Admission ticket sales & $70 \mathrm{mil}$ \\
\hline & Total & $\mathbf{4 4 0} \mathbf{~ m i l}$ \\
\hline
\end{tabular}

Source :Author's interview in November, 2017

\subsection{Actors involved in the festival's organization}

Several actors were involved in the preparation and organization of the festival (Fig.1). However, the extent of their involvement varied considerably. The Executive Committee consisted of 24 members, including representatives of several local organizations and groups, as well as local authorities. The Board of the committee was constituted by five members: the Mayor of Suzu; the Chairman of the City Chamber; the President of the Chamber of Commerce; the President of the local cultural association; and the President of the local community association. The General Director of the festival, Fram Kitagawa, who is also the President of AFG, was involved as an advisory member.

The directives issued by the Board and the Executive Committee were implemented by different parties (Table 2). The "AFG team" was mainly in charge of preparing the artworks. The Committee and local authorities mainly managed on-field logistical matters, such as preparing spaces for the display of artworks and recruiting volunteers. In addition, a nine-member team also worked full-time to ensure that the festival functioned smoothly. This team included eight individuals nominated by the municipal office and one person nominated by the Chamber of Commerce.
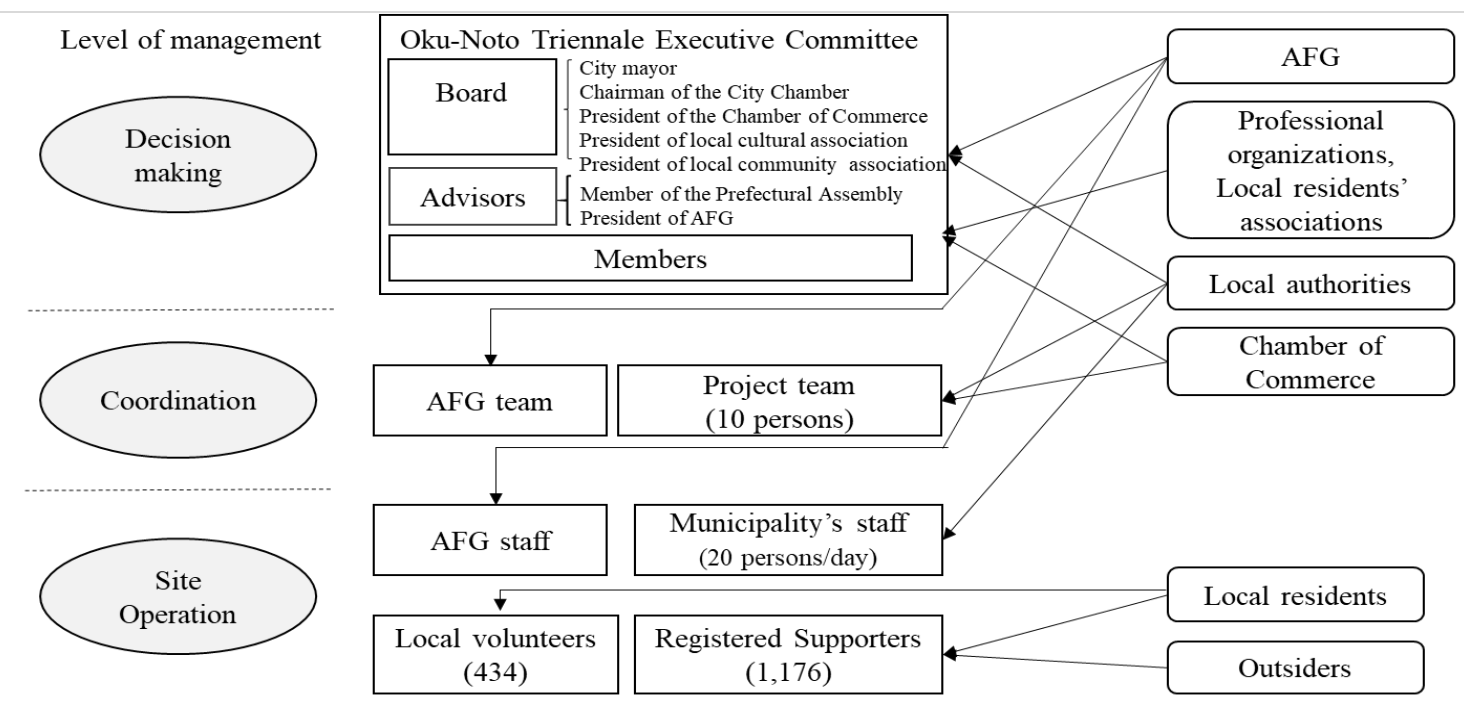

Figure 1. Actors involved in the Oku-Noto Triennare Source: Authors' interview in January, 2018. 
Volunteers also contributed to the organization of the festival. Most (85\%) of registered supporters, called "supporters," were people from outside Suzu including $14 \%$ who were international supporters. Local residents were often non-registered helpers, who volunteered on the spot. In total, 1,176 people were involved as registered supporters, and 434 residents were involved as local volunteers during the festival (counted in working-days).

The number of organizers, representatives, and volunteers present at the sites during the festival varied (Fig. 2). For instance, two weeks before the festival, four of AFG's employees were sent to Suzu for a two-month period to help with the preparations. Four or five more AFG staff members were sent during the weekends as well as during special events. Furthermore, the number of residents involved in the organization of the festival also changed significantly. The number of volunteers increased as the residents' understanding of the kind of artworks required for the festival improved. In addition, the City Hall sent more employees to help during the festival whenever there was a shortage of staff. The municipal office sent as many as 20 people to the field per day on a rotational basis. On average, each municipal office employee was a helper for one day per week during the festival.

Table 2. Distribution of the tasks between the organizing actors

\begin{tabular}{|c|c|c|}
\hline Actor & Roles & Tasks \\
\hline \multirow[t]{2}{*}{$\begin{array}{l}\text { Committee and } \\
\text { Local Authority }\end{array}$} & $\begin{array}{l}\text { Logistical } \\
\text { aspects }\end{array}$ & $\begin{array}{l}\text { Gathering and coordination of the supporters } \\
\text { Organization of the bus tours } \\
\text { Preparation of spaces (artworks, parking lots) } \\
\text { Preparation of the collaboration with local businesses }\end{array}$ \\
\hline & Information & $\begin{array}{l}\text { Information for local residents } \\
\text { Inviting artists to visit the region to choose artwork } \\
\text { location } \\
\text { Preparation of necessary information for the artists }\end{array}$ \\
\hline \multirow[t]{2}{*}{ AFG } & $\begin{array}{l}\text { Artistic } \\
\text { management of } \\
\text { the festival }\end{array}$ & $\begin{array}{l}\text { Planning the festival's format } \\
\text { Selection of artists } \\
\text { Programming of events }\end{array}$ \\
\hline & Communication & $\begin{array}{l}\text { Promotional activities: conferences } \\
\text { Meetings with local residents } \\
\text { Link between artists and residents }\end{array}$ \\
\hline \multirow[t]{2}{*}{$\begin{array}{l}\text { Registered } \\
\text { Supporters/Local } \\
\text { Volunteers }\end{array}$} & "work force" & $\begin{array}{l}\text { Before the festival } \\
\text { Preparation, maintenance of the artworks' locations } \\
\text { Providing materials, objects, and machines necessary } \\
\text { for the artworks conception } \\
\text { Participation in the conception of artworks } \\
\text { Advising about the installation of artworks }\end{array}$ \\
\hline & & $\begin{array}{l}\text { During the festival } \\
\text { Bus guide } \\
\text { Reception work } \\
\text { Management of the parking lots } \\
\text { Distribution of event flyers }\end{array}$ \\
\hline
\end{tabular}

Source: Authors' interview in January, 2018. 


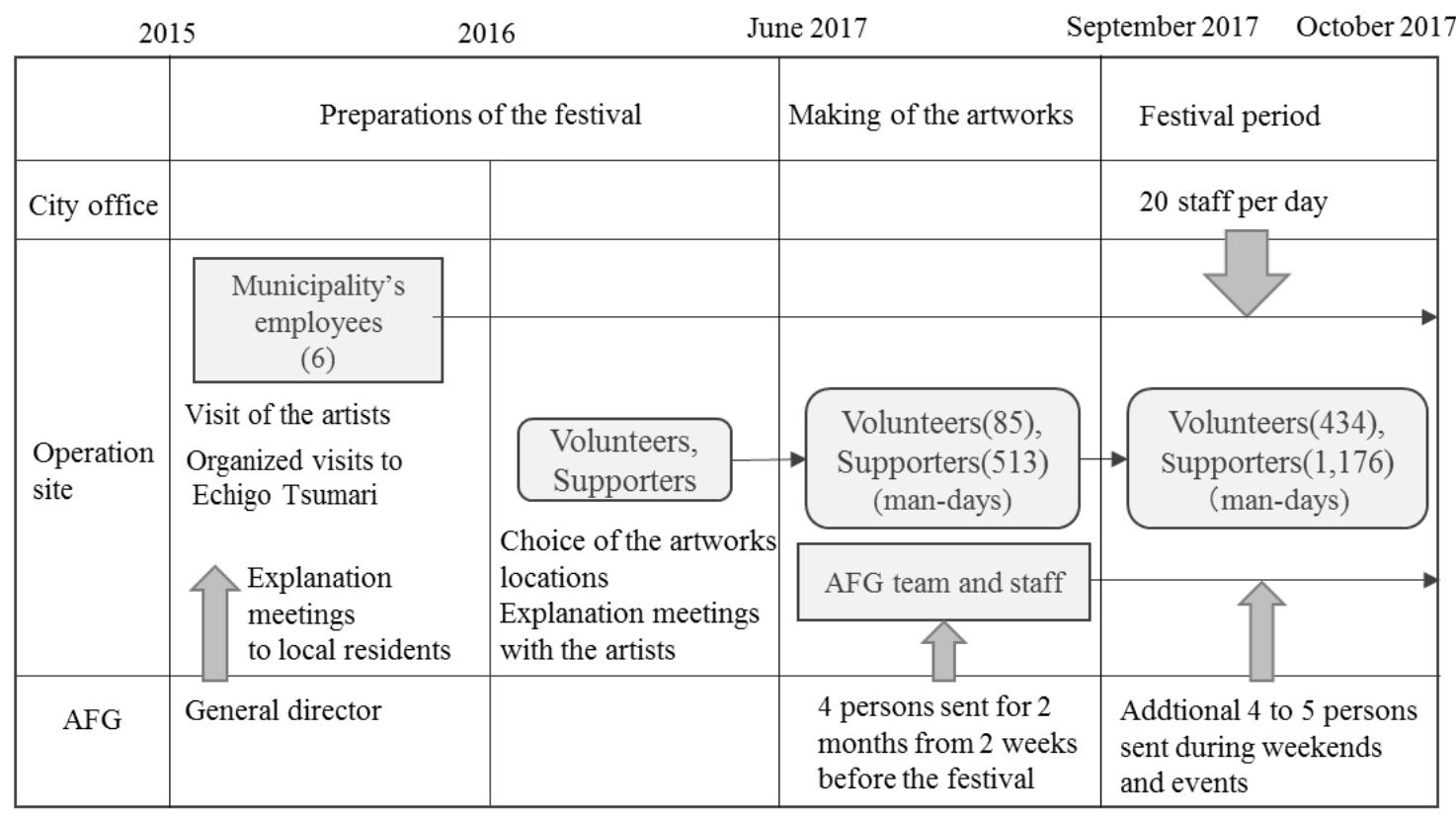

Figure 2. Evolution of the staff on the operation site

Source: Authors' interview in November, 2017 and January, 2018.

\subsection{Preparation process}

The preparations for the festival began in 2014, a process that eventually took almost three and a half years. The President of AFG made the artist-related decisions and also served as the festival's General Director. The artists were either directly invited or selected through an open competition.

Following this, the organizers requested the selected artists to choose the ideal locations to display their artworks. This process involved several steps. For instance, members of the City Hall were required to familiarize the artists with Suzu and its surroundings to ensure that the work was place-based, and to help them choose the ideal location. Guided visits were organized for all artists in 2015. During the visit, the guides provided information about Suzu and its surroundings; offered information about the facilities available in the region, as well as its history and traditions.

Once the locations were determined, the artists met the residents to explain and discuss their plans. Together, they identified how to transform the sites into display areas. Based on AFG's advice, the creation of artworks began about two or three months prior to the festival. This decision was influenced by an analysis of other festivals: beginning the construction process earlier would only have increased the festival's organizational costs.

The logistical preparations also took two years. The organizers collaborated with local businesses to enable visitors to discover local specialties. The last few pages of the festival pass listed all the discounts offered by the local shops and restaurants involved in the festival. This arrangement was secured by members of the City Office who had experience of such deals. Bus tours connecting all locations that displayed the artworks were arranged by municipality employees. In addition, the municipality was also 
involved in preparing parking lots, collecting information for artists, and organizing public relations activities to establish connections with local residents.

Promotional talks were organized at the national level to promote the festival. For instance, ten-days of promotional talks were organized in Shibuya, Tokyo; similarly, a promotional forum was organized in Kanazawa, Ishikawa Prefecture. An English version of the festival's website was also developed to promote the festival internationally.

Table 3. Main results of the festival

\begin{tabular}{lc}
\hline \hline \multicolumn{1}{c}{ Criteria } & $\begin{array}{c}\text { Results } \\
\text { (the number of people/tickets sold) }\end{array}$ \\
\hline Visitors in total & 71,000 \\
\hline Sold passports (common admission ticket) & 26,500 \\
\hline Sold separate tickets & 26,754 \\
\hline Bus tour users & 3,001 \\
\hline Rented bikes users & 400 \\
\hline Source: Oku-Noto Triennale Executive Committee (2018b).
\end{tabular}

\subsection{Results and evaluation}

According to the Suzu City and representatives of AFG, the festival was more successful than expected. The local government expected to attract 30,000 visitors. This number was decided upon as a realistic target based on previous festivals in other locations. The festival attracted twice the number of expected visitors: in total, 71,000 people visited. Thus, the number of tickets and passports sold also surpassed initial expectations (Table 3). According to the official report (Oku-Noto Triennale Executive Committee, 2018b), visitors' direct spending was estimated as 418 mil JPY, which exceeded the amount total of public funds and private donations spent on the festival.

In general, all the locations were found to be equally popular, regardless of their accessibility. Barring the mountainous locations, which drew a little less than 8,000 visitors each, all the other locations drew as many as 10,000 visitors each. In addition, all four bus tours ran at almost full capacity every day, and in many cases, visitors who had not booked these tours had to find alternative ways to explore the sites. The residents were also satisfied with the festival; they expressed their satisfaction with the artworks and festival events, and they were also pleased with the community involvement opportunities that the festival created. They revealed that the festival offered them some hope for the town's future development.

Nonetheless, local authorities and AFG representatives pointed out some areas that required improved organization. This was quite natural given that this was the first edition of the festival. Some concerns required immediate attention, and adjustments had to be made during the festival itself. For instance, it was observed that the visitors found it difficult to travel to the various display locations. Some locations were hard to find, while others had to be visited during the night to fully appreciate the artwork (i.e., light installations); this was mainly due to a lack of appropriate information and indications. To alleviate this problem, more directional signs were introduced during the first week of the festival. In addition, some locations did not have enough parking space. 
The festival's timings, in particular, the opening time, also received criticism. For logistical reasons, the festival was scheduled to open at 9:30 AM and close at 17:00 PM every day. The staff gathered at 8:00 AM and departed to their assigned locations by 8:30 AM; typically, they prepared the locations between 9:00 and 9:30 AM. However, visitors often arrived earlier, and this caused a few problems.

One of the biggest problems during the festival was the constantly changing number of support staff. On an average basis, the organizational team required 40 to 50 people every day. At some locations, they required two people to manage the reception. The strict minimum was 30 people per day; it should be noted that there were 28 locations in total. Although the organizational team was able to attract enough support staff during the weekends, they found it especially difficult to find support staff during the weekdays. During weekends, the organizational team was assisted by volunteers from outside the city and helpers from AFG. The municipality noticed this issue during June-July, 2017. It assigned twenty of its employees to the festival locations every day to help with the sites' operations. In addition, volunteers' participation and involvement in the festival was rather unpredictable. Residents were especially enthusiastic about volunteering in locations with a good ambiance. Therefore, it will be necessary to enlist more supporters in the future. To this end, it would be advisable to form a bottom-up association involving local residents. For example, a non-profit organization was formed to increase the volunteer base for the Echigo-Tsumari Art Triennale.

Suzu is a small and remote city; its tourism industry is not large enough to accommodate a large number of visitors. Therefore, it was particularly difficult to arrange sufficient hospitality services. It will be necessary to increase the number of pensions and guesthouses to address this issue. According to the local authorities, some of their unused facilities could serve as hospitality venues.

In addition, the festival was not popular at an international level. Therefore, it will be necessary to improve local promotional practices to attract more international visitors.

\section{The involvement of residents in the preparation and organization of the festival}

\subsection{Residents' involvement}

In total, ten districts of Suzu were involved in the festival. According to the local authorities, the ten districts consist of 160 wards. As stated above, the organizers actively sought to encourage residents to participate in the festival's preparation. The slogan stated the "the festival organized by 15,000 residents." To ensure the residents' participation, the organizational team first had to convey the festival's underlying concept to the residents. More importantly, for the festival to succeed, the concept had to be socially acceptable. This was quite difficult at first, as people did not know much about the concept of art festivals. Therefore, the organizational team scheduled several initiatives to popularize the rural arts festival and to highlight the festival's participatory approach. In 2015, the festival's General Director visited all districts in the city of Suzu to explain this concept. However, only a few people attended these meetings. During the same year, the local authorities organized several bus tours to the Echigo-Tsumari Art Triennale, and each tour accommodated 100 residents. 
By the spring of 2017, residents were rather keen to be involved in the festival's organization, especially after the artists were invited to explain their projects to the local community. According to the municipality employees we interviewed, residents' participation and efficiency grew to more than expected.

The artwork that involved one of the highest numbers of residents was Sazae House, by artist Kazuko Murao; notably, the house was covered with Sazae shells. Residents were particularly enthusiastic about collecting, sorting, and preparing the shells. On the other hand, Konoike Tomoko's Table Runner required the most amount of time. Residents were also involved in preparing the artworks displayed in Kamikuromaru and Hiki house.

\subsection{Example 1: Kamikuromaru}

Kamikuromaru is a mountainous rural community, which houses about 360 inhabitants. It is further divided into ten smaller communities. Artworks were displayed in the following three communities: Kamikuromaru, Kitayama, and Minamiyama (Table 4).

Kamikuromaru is also known for the Kamikuromaru Art Project. The project was conceptualized by the "Kurominekai" and Kanazawa College of Art in 2011. The "Kurominekai" is the group who govern the Kamikuromaru communities. This project aims to revive the community surroundings and facilitate the rediscovery of Oku-Noto's culture through art. To this end, an art residence program was founded in a former elementary school. Every summer, the residence displays the works of art students from Kanazawa College of Art. The three artists who displayed their works in Kamikuromaru during the festival have strong links with the community. For instance, artist Koji Nakase has been participating in the Kamikuromaru Art Project for the last seven years; Masami Sakamaki has been participating in the project for the last four years, and Daisuke Takekawa has been participating for the last two years. These artists were selected by AFG based on the recommendation of the local authorities.

Thus, the community actively supported the artists, but also artistic work equally supported the community by offering new ways of looking at community symbols and traditions (see also Table 4). The residents were involved in preparing the space for the display of artworks; they were also involved in procuring the necessary materials (Table 5). In addition, they provided food and accommodation to the artists and students. The involvement of the residents was managed and supervised by an assigned representative who also came from Kamikuromaru.

Community involvement was also evidenced on its own terms beyond artistic engagement. For example, Kamikuromaru residents planned and implemented a project by themselves. The project was intended as a welcome to visitors. To this end, the residents distributed potatoes grown by the local farmers and households. The potatoes were boiled in the traditional manner: in a big jar and on a wooden fire. The potatoes were mainly distributed during the weekends. The idea for this project emerged in May, 2017. All households in the community were invited to participate in the project by providing potatoes. In total, 50 households (from the 10 communities) participated in the project. In addition, a total of 6,250 potatoes totaling $406 \mathrm{~kg}$ were gathered. This project aimed to create awareness of Kamikuromaru's customs. According to the local representative, those who visited Kamikuromaru from nearby areas tended to feel 
nostalgic, whereas others claimed to have rediscovered the taste of potato. In sum, the festival inspired the residents to organize activities which promoted their community customs.

Table 4. Artworks exhibited in Kamikuromaru

\begin{tabular}{|c|c|c|c|}
\hline Location & Title & Artist & Description \\
\hline Kamikuromaru & $\begin{array}{l}\text { Moon-reflecting } \\
\text { Flower Stage }\end{array}$ & $\begin{array}{l}\text { Koji } \\
\text { Nakase }\end{array}$ & $\begin{array}{l}\text { - White scales set in the yard with small } \\
\text { cloths tied on it by the visitors (interactive } \\
\text { art) } \\
\text { - Installation of a round yellow platform to } \\
\text { enjoy the moon and a jar to see the refection } \\
\text { of the sky }\end{array}$ \\
\hline Kitayama & $\begin{array}{l}\text { Kamikuromaru } \\
\text { Kitayama } \\
\text { A Whaling group } \\
2017\end{array}$ & $\begin{array}{l}\text { Masami } \\
\text { Sakamaki }\end{array}$ & $\begin{array}{l}\text {-Installation showing the old traditional } \\
\text { dispositive to fish, with colored fishermen } \\
\text { flags and boat } \\
\text {-Paintings of whale fishing indication } \\
\text { symbols of the traditional lifestyle }\end{array}$ \\
\hline Minamiyama & $\begin{array}{l}\text { Of the sea; about } \\
\text { the mountain }\end{array}$ & $\begin{array}{l}\text { Daisuke } \\
\text { Takekawa }\end{array}$ & $\begin{array}{l}\text {-Reconstitution of ancient peddling traditions } \\
\text { between the sea/mountain communities to } \\
\text { make a movie about it. } \\
\text {-Bamboo installation, small circular huts at } \\
\text { the cross roads between five communities: } \\
\text { multi purposes installations (meeting place, } \\
\text { scene for performances). }\end{array}$ \\
\hline
\end{tabular}

Source: Authors' interview in January, 2018

Table 5. Involvement of locals in Kamikuromaru

\begin{tabular}{|c|c|c|}
\hline & Task & $\begin{array}{ll}\text { Example } \\
\end{array}$ \\
\hline \multirow[t]{4}{*}{$\begin{array}{l}\text { Preparation } \\
\text { process }\end{array}$} & $\begin{array}{l}\text { Preparation of the } \\
\text { artwork location }\end{array}$ & $\begin{array}{l}\text { - Weeding, cleaning the needed space } \\
\text { - For Kitayama, digging of the old paddy field to } \\
\text { flood again with water }\end{array}$ \\
\hline & $\begin{array}{l}\text { Preparation of the needed } \\
\text { materials }\end{array}$ & $\begin{array}{l}\text { - For Kitayama, cut the wood, take off the bark } \\
\text { - Provide the jar for Nakase }\end{array}$ \\
\hline & $\begin{array}{l}\text { Provide the needed } \\
\text { machines }\end{array}$ & - Handling of a mobile crane \\
\hline & $\begin{array}{l}\text { Advise the artist with } \\
\text { local knowledge }\end{array}$ & $\begin{array}{l}\text { - To carpenters: kind of rope to use for the } \\
\text { wooden installation, tips to build it } \\
\text { - Choice of the paddy field to be used }\end{array}$ \\
\hline \multirow[t]{2}{*}{$\begin{array}{l}\text { During the } \\
\text { festival }\end{array}$} & Logistical support & $\begin{array}{l}\text { - Management of the parking lots } \\
\text { - Guidance during visits } \\
\text { - Distribution of flyers }\end{array}$ \\
\hline & Potato project & $\begin{array}{l}\text { - Gathering of } 6,250 \text { potatoes }(406 \mathrm{~kg}) \\
\text { - } 22 \text { distribution events of boiled potatoes to } \\
\text { visitors }\end{array}$ \\
\hline
\end{tabular}

Source: Authors' interview in January, 2018

The festival also rekindled a local community spirit. By working together for a common objective, the residents formed stronger social bonds, not only with each other, 
but also with volunteers who came from different regions and the students of Kanazawa University. The festival attracted more people than the residents had anticipated. Although a few people did not understand the concept of an outdoor or rural art festival, they were nonetheless aware that something significant was taking place: "Witnessing people and cars coming, information [about the festival] being spread on TV, a large number of people sensed that something different was happening." Although the residents were relieved when the festival was over, they also looked forward to the next edition.

\subsection{Example 2: Patchwork}

Tomoko Konoike's "Table Runner," displayed in downtown Iida district in Suzu, is a good example of how Suzu's residents were engaged in the festival. It also shows how the artist can highlight local residents' skills in line with socially engaged art practices (Table 6). The concept, which Konoike had already used in Akita, Aomori, and Tasmania, was to enable the residents to express themselves through handicraft. To this end, the residents were required to bring back a memory from their past. The artist then drew sketches based on the contents of the note. Female participants (all local residents) were then responsible for making matching handicraft pieces. The whole process took about three months.

Table 6. Patchwork artwork exhibited in Iida

\begin{tabular}{cllll}
\hline \hline Location & Title & Artist & \multicolumn{1}{c}{ Description } \\
\hline Iida & Table & Tomoko & Exhibition of 27 & handicraft (patchwork, embroidery) \\
& Runner & Konoike & pieces sewn by 27 local women, depicting memories of \\
& - Suzu & & their past. & \\
\hline \multicolumn{5}{c}{ Source: Authors' interview in January, 2018 }
\end{tabular}

Source: Authors' interview in January, 2018

This project was quite easy to initiate because there was an existing handicraft group called "Yume Nuno" in the region. The group was formed about 20 years ago, and brings together local women interested in learning patchwork and other sewing techniques. Konoike was introduced to the group when she was looking for people to participate in her project. Of the 27 people who participated in this project, 20 belonged to this group.

During the festival, the artworks were displayed with the texts they were based on (Photo 1). In total, three women addressed the visitors every day: two managed the reception, and one explained the concepts behind the artworks. Almost all the women participants involved in the sewing undertook these tasks on a rotational basis.

The women dedicated a lot of time and also invested emotionally in this project. According to one of the women we interviewed, participating in this project had several benefits. At an individual level, the woman claimed the project was a source of energy and motivation. She claimed that it also reinforced social cohesion by allowing them to meet new people and strengthen their links with others involved in the project. Moreover, the city was livelier during the festival, and the residents were also very supportive. All the women were satisfied to have participated in the project, and were even excited about having been able to so. 


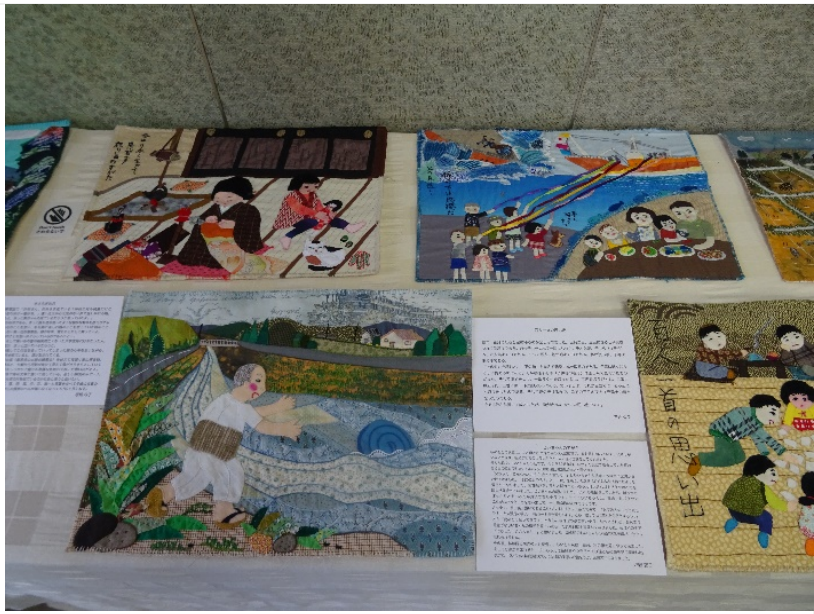

Photo 1. "Table Runner-Suzu"

In addition, the festival itself was well perceived by the interviewees. It was a great source of relief that the festival was funded by resources previously allocated for a nuclear plant. This played a big role in opening people's minds to the idea of hosting a contemporary art festival. Although this was not the kind of festival they were used to, the residents gradually came to understand the value of the festival, as well as the value of art. The festival enabled them to rediscover the beauty of their land. It also took them to places they would not have visited otherwise. Residents also appreciated the artists' efforts to understand the history of the city and the wider region. They reported feeling hopeful about the long-term prospects of the region's development owing to the festival. According to one interviewee, one of the keys to the festival's success might have been the positive value and respect conveyed for the community's' feelings and its history.

\section{Conclusion}

This paper investigated the management process of the first edition of the Oku-Noto Triennale, a particularly underdeveloped area of research in rural studies. Drawing on in-depth interviews with community participants and festival organizers, we conclude that the festival achieved its stated objectives, and was positively received by visitors and local residents alike. This was partly due to effective preparation and organization, as well as the community's engagement in the festival. In particular, the following aspects of the festival's organization were responsible for its success.

First, the various actors involved in the festival's organization were managed efficiently. The flexibility of the organizing team, for example, assigning additional municipality employees to site operations, was pivotal. The actors' abilities to address and overcome the difficulties they faced during the preparation also deserves mention. Experienced actors, such as outside professionals, and residents who had experience organizing previous projects, were involved in this festival's organization which also contributed to its success.

The festival also succeeded in the involvement of residents. This is especially important should more editions of this festival be organized. The organizing team 
worked hard to convey the underlying concept of the art festival to the local residents. Doing so was essential to encourage their involvement and active participation. In this context, the visits to the Echigo-Tsumari Art Triennale were especially helpful. Linking the artworks with the region's identity and sense of place was also pivotal. It enabled the residents to reconnect with the city and its surroundings. By organizing the festival, the residents met and formed bonds with new people and also strengthened their ties with one another.

The next edition of this festival is likely to be staged in 2020. Therefore, it will be necessary to focus on the areas requiring improvement. Our research highlighted the following points for attention: first, it is important to have a sufficient number of staff to organize the festival. To this end, it will also be necessary to accurately predict the number of visitors and plan accordingly. Also, volunteers need to be better organized to avoid a shortage of staff. Finally, more lodging and hospitality services must be provided for visitors. Notably, the organizing team has already started working on these issues.

\section{References}

Crawshaw, J. and M. Gkartzios. 2016. Getting to know the island: Artistic experiments in rural development. Journal of Rural Studies 43: 134-144.

Crawshaw, J. and M. Gkartzios. 2018. The way art works: Insights for community development. In S. Kenny, B. McGrath and R. Phillips (Eds.). The Routledge Handbook of Community Development. London: Routledge, pp. 177-192.

Demetriou. D. 2009. Zen and the art of rural regeneration. The Guardian: https://www.theguardian.com/travel/2009/aug/01/art-festival-japan-echigotsumari

Echigo Tsumari Exective Committee. 2018. About Echigo-Tsumari Art Field: http://www.echigo-tsumari.jp/eng/about/overview/. 2018-02-16

Favell A. 2015. Islands for life: Artistic response to remote social polarization, sustainability in contemporary rural Japan: Challenges and opportunities. London: Routledge, pp: 109-124.

Gibson, C., G. Waitt, J. Walmsley, and J. Connell. 2010. Cultural festivals and economic development in nonmetropolitan Australia. Journal of Planning Education and Research. 29(3): 280-293.

Gibson, C., J. Connell and J. Walmsley. 2010. The extent and significance of rural festivals. In Gibson, C., and Connell, J. (Eds.), Festival places: Revitalising rural Australia. Bristol: Channel View Publications, pp: 3-24.

Gkartzios, M. and J. Crawshaw, 2019. Researching rural housing: With an artist in residence. Sociologia Ruralis. DOI: 10.1111/soru.12224 (in press).

Gursoy, D., K. Kyungmi and M. Uysal. 2004. Perceived impacts of festivals and special events by organizers: An extension and validation. Tourism Management 24: 171181.

Karasawa. T. 2007. The process of human resources development by cultural policy: fieldwork in "Echigo-Tsumari Art Triennial 2003 and 2006". Doshisha University Policy \& Management Review. 9(1): 133-142. (in Japanese). 
Kitagawa F., 2015. Art Place Japan: The Echigo-Tsumari Triennale and the vision to reconnect art and nature. Princeton Architectural Press, New York.

Kobayashi. R. 2005. Research on revitalizing depopulated regions through the use of art (part two): Evaluation of the cultural aspects of the nature art festival and "Echigo Tsumari Art Necklace Construction”. Hokusei Review, Junior College 3: 11-27 (in Japanese).

Kobayashi R. 2014. The role of art projects for the aging society of Japan in the context of rural regeneration: Entering a new era of asking why we need "art" projects? Japanisch-Deutches Zentrum, Berlin, pp 101-124.

Kudo S., E. Mutisya, and M. Nagano. 2015. Population aging: An emerging research agenda for sustainable development. Social Sciences 4: 940-966.

Maerkle. A. 2017. Contested constellation. Frieze: https://frieze.com/article/contestedconstellation

Mahon, M. and T. Hyyrylaïnen, 2017. Rural place development through commodification of art and culture: An investigation of the construction of art narratives. Paper presented at the European Society for Rural Sociology congress, 24-27 July, Krakow, Poland.

Oku-Noto Triennale Executive Committee. 2018. Artists: http://oku-noto.jp/en/artists/. 2018-02-16

Oku-Noto Triennale Executive Committee. 2018b. Comprehensive report of Oku-Noto Triennale 2017 (in Japanese).

Statistics Bureau of Japan. 2015. National Census: https://www.e-stat.go.jp/regionalstatistics/. 2018-02-16

Sumi. E. 2013. A Questionnaire study of Echigo-Tsumari Art Field 2012. The Journal of Economics, Niigata University. 94: 251-280. (in Japanese).

Whatley. K. 2018. Echigo-Tsumari Art Triennale: Niigata's fields of art and inspiration. The Japan Times: https://www.japantimes.co.jp/culture/2018/07/01/arts/echigotsumari-art-triennale-niigatas-fields-art-inspiration/\#.W3ihh-hKjIU 